\title{
Kemampuan Metakognisi dalam Pemecahan Masalah Matematika Siswa Kelas VIII.A SMP Hang Tuah Makassar
}

\author{
Syamsuriyawati ${ }^{1^{*}}$, Rahmawati $^{2}$, Nirfayanti ${ }^{3}$ \\ 1) 2) 3) Pendidikan Matematika, FKIP Universitas Muslim Maros \\ ${ }^{1)}$ wathy@umma.ac.id \\ ${ }^{2)}$ nyoled@umma.ac.id \\ 3) nirfa@umma.ac.id
}

\begin{abstract}
ABSTRAK
Jenis penelitian ini adalah penelitian kualitatif deskriptif yang bertujuan untuk mengetahui kemampuan metakognisi dalam pemecahan masalah matematika siswa kelas VIII.A SMP Hang Tuah Makassar. Subjek penelitian ini adalah siswa kelas VIII.A dengan mengambil 3 orang siswa yang mewakili kelompok kemampuan tinggi, sedang, dan rendah. Instrumen yang digunakan dalam penelitian ini adalah tes dan wawancara. Teknik analisis data yang digunakan adalah reduksi data, penyajian data, dan penarikan kesimpulan. Hasil penelitian menunjukkan bahwa subjek penelitian dengan kemampuan tinggi dapat menyelesaikan soal yang diberikan, hampir semua indikator terpenuhi pada masing-masing proses perencanaan (planning), pemantauan (monitoring), maupun evaluasi (evaluation). Untuk subjek dengan kemampuan sedang dalam pemecahan masalah tidak lebih baik dibanding kelompok tinggi saat merencanakan penyelesaian pada masing-masing proses perencanaan (planning), pemantauan (monitoring), maupun evaluasi (evaluation). Kemudian untuk subjek dengan rendah dalam pemecahan masalah semua indikator tidak terpenuhi pada masing-masing proses perencanaan (planning), pemantauan (monitoring), maupun evaluasi (evaluation).
\end{abstract}

Kata kunci : Kemampuan Metakognisi, Pemecahan Masalah Matematika, SMP Hang Tuah Makassar.

\begin{abstract}
This type of research is descriptive qualitative research that aims to determine the ability of metacognition in solving mathematical problems of class VIII.A students of Hang Tuah Junior High School Makassar. The subjects of this study were students of class VIII.A by taking 3 students representing the high, medium, and low ability groups. The instruments used in this study were tests and interviews. Data analysis techniques used are data reduction, data presentation, and concluding. The results showed that research subjects with high abilities were able to solve the given questions, almost all indicators were met in each planning, monitoring, and evaluation process. For subjects with moderate ability in problem-solving, it is not better than the high group when planning the completion of each planning, monitoring, and evaluation process. Then for subjects with low problem solving, all indicators are not met in each planning, monitoring, and evaluation process.
\end{abstract}

Keywords: Metacognition Ability, Mathematical Problem Solving, SMP Hang Tuah Makassar 


\section{A. PENDAHULUAN}

Matematika adalah suatu disiplin ilmu yang muncul dari sebuah proses peradaban manusia. Peradaban sendiri akan tercipta dan hanya dapat dikembangkan oleh manusia yang berpikir kritis, cermat, logis, sistematis, kreatif, dan inovatif. (Nurmalasari et al., 2015)

Peranan matematika dalam mengembangkan kemampuan berpikir seseorang yang menjadikan matematika sebagai suatu sarana yang memegang peranan yang cukup besar dalam mengembangkan ilmu pengetahuan dan teknologi. Namun, kenyataan yang ada begitu berbeda, hampir setiap siswa menganggap mata pelajaran matematika adalah pelajaran sulit dan mayoritas siswa tidak tertarik dengan matematika. Salah satu penyebabnya yakni pembelajaran matematika yang syarat akan konsep-konsep matematis tanpa disertai implementasinya dalam kehidupan sehari-hari. Akan tetapi, kemampuan menyelesaikan masalah merupakan tujuan umum pengajaran matematika, maka siswa haruslah belajar matematika agar dapat membantu dirinya dalam memecahkan persoalan baik dalam pelajaran lain maupun dalam kehidupan seharihari (Putri \& Tayeb, 2017).

Proses menyadari kemampuan dan mengatur berpikir siswa dalam memecahkan masalah dikenal sebagai metakognisi. Menurut Flavell metakognisi sebagai kemampuan untuk memahami dan memantau berpikir diri sendiri dan asumsi serta implikasi kegiatan seseorang. Pendapat ini menekankan metakognisi sebagai kemampuan untuk memahami dan memantau kegiatan berpikir, sehingga proses metakognisi tiap-tiap orang akan berbeda menurut kemampuan (Anggo, 2011:26).

Dalam penelitian ini, penulis mengacu pada penelitian terdahulu yang relevan dengan penelitian yang akan dilaksanakan, yakni penelitian Nurmalasari, et al. (2015) yang berjudul "Pengaruh Kemampuan Metakognisi terhadap Hasil Belajar Matematika di SMP Negeri 2 Leuwimunding Kabupaten Majalengka", dari hasil penelitiannya ditemukan bahwa semakin baik kemampuan metakognisi yang dimiliki siswa maka semakin baik juga hasil belajar yang diperoleh. Begitupun juga dengan penelitian yang dilakukan oleh Anggo (2011) yang berjudul "Pelibatan Metakognisi dalam Pemecahan Masalah Matematika" menyimpulkan bahwa metakognisi berperan penting terutama dalam meningkatkan kemampuan belajar dan memecahkan masalah.

Berdasarkan uraian di atas, adapun rumusan masalah dalam penelitian ini adalah Bagaimana kemampuan metakognisi dalam pemecahan masalah matematika siswa kelas VIII.A SMP Hang Tuah Makassar?

\section{B. METODE}

\section{Jenis Penelitian}

Penelitian ini termasuk penelitian kualitatif deskriptif yang bertujuan untuk mengetahui kemampuan metakognisi dalam pemecahan masalah matematika siswa. 


\section{Populasi, Sampel, dan Variabel Penelitian}

Subjek dalam penelitian ini adalah siswa kelas VIII.A SMP Hang Tuah Makassar dengan mengambil 3 orang siswa mewakili kelompok kemampuan rendah, sedang, dan tinggi.

\section{Prosedur Pelaksanaan Penelitian}

a. Tahap Persiapan, yaitu: melakukan observasi ke SMP Hang Tuah Makassar; mengajukan surat permohonan izin penelitian kepada kepala sekolah SMP Hang Tuah Makassar; dan menyusun instrumen.

b. Tahap Pelaksanaan, yaitu: pemberian tes; memeriksa hasil tes dan mengelompokkan kemampuan rendah, sedang dan tinggi; mewawancarai subjek penelitian untuk mendapatkan informasi.

\section{Instrumen Penelitian}

Instrumen yang digunakan dalam penelitian ini yaitu lembar tes pemecahan masalah dan pedoman wawancara. Lembar tes berupa soal pemecahan masalah yag terdiri dari 2 soal uraian. Sedangkan pedoman wawancara digunakan untuk menggali informasi tahap metakognitif yang dilakukan oleh subjek penelitian, wawancara yang dilakukan adalah wawancara terbuka yang mana pertanyaan bisa berkembang disaat proses wawancara dilakukan.

\section{Teknik Pengumpulan dan Analisis data}

Teknik analisis data yang digunakan adalah metode seperti yang dikemukakan oleh Miles dan Huberman (Sugiyono, 2012) yaitu reduksi data, penyajian data, dan penarikan kesimpulan. Untuk menjamin keabsahan data, maka dilakukan triangulasi. Triangulasi dilaksanakan menggunakan triangulasi metode, yakni dengan membandingkan hasil tes dan hasil wawancara.

\section{HASIL PENELITIAN DAN PEMBAHASAN}

Hasil tes yang dilakukan di kelas VIII.A dengan jumlah siswa 32 orang, diperoleh hasil pekerjaan siswa dengan skor yang berbeda-beda. Selanjutnya peneliti mengurutkan skor-skor-skor tersebut dari yang tertinggi sampai yang terendah, dan akhirnya dipilih 3 subjek mewakili kemampuan tinggi, sedang, dan rendah. Berikut disajikan analisis data kemampuan metakognisi berdasarkan hasil tes tertulis dan wawancara siswa dapat dilihat pada tabel 1

Tabel 1 Rekapitulasi Data Hasil Tes dan Wawancara

\begin{tabular}{cll}
\hline $\begin{array}{c}\text { Kelompok } \\
\text { Pemecahan } \\
\text { Masalah }\end{array}$ & \multicolumn{1}{l}{ Indikator Kemampuan Metakognisi dalam Pemecahan Masalah } & Keterangan \\
\hline \multirow{3}{*}{ Tinggi } & $\begin{array}{l}\text { Memahami Masalah } \\
\text { 1. Perencanaan (planning) } \\
\text { Merencanakan pemahaman masalah, antara lain: } \\
\end{array}$ & $\begin{array}{l}\text { Semua } \\
\text { indikator } \\
\text { t.1 Menentukan yang diketahui dari permasalahan yang diberikan. }\end{array}$ \\
\hline
\end{tabular}




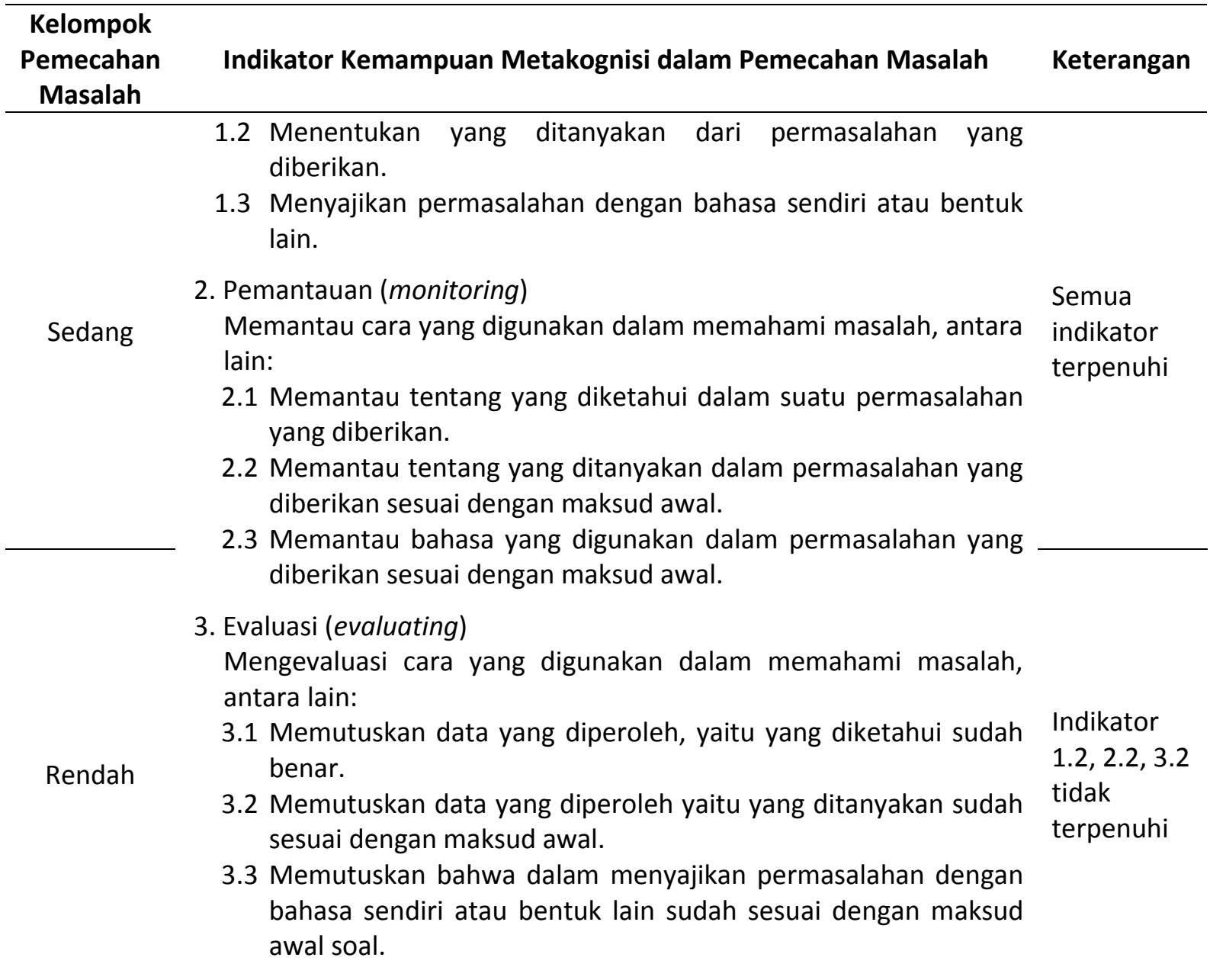

\section{Merencanakan Penyelesaian}

1. Perencanaan (planning)

Memikirkan perencanaan penyelesaian, antara lain:

1.1 Memikirkan hubungan antara yang diketahui dengan yang ditanyakan.

Tinggi 1.2 Memikirkan untuk mencari beberapa strategi/cara yang tepat untuk menyelesaikan soal yang diberikan.

Indikator

1.2 tidak terpenuhi

1.3 Memikirkan konsep matematika yang dapat membantunya dalam menyelesaikan soal.

1.4 Merencanakan waktu yang digunakan untuk menyelesaikan soal

2. Pemantauan (monitoring)

Memantau cara yang digunakan dalam merencanakan penyelesaian, antara lain:

2.1 Memantau hubungan antara yang diketahui dengan yang ditanyakan sudah tepat.

2.2 Memantau strategi/cara yang tepat untuk menyelesaikan soal yang diberikan.

2.3 Memantau bahwa konsep matematika yang digunakan sudah sesuai.
Indikator

2.2 dan 3.2

tidak

terpenuhi 


\begin{tabular}{|c|c|c|}
\hline $\begin{array}{c}\text { Kelompok } \\
\text { Pemecahan } \\
\text { Masalah }\end{array}$ & Indikator Kemampuan Metakognisi dalam Pemecahan Masalah & Keterangan \\
\hline Rendah & $\begin{array}{l}\text { 3. Evaluasi (evaluating) } \\
\text { Mengevaluasi cara yang digunakan dalam merencanakan } \\
\text { penyelesaian, antara lain: } \\
\text { 3.1 Memutuskan bahwa hubungan antara yang diketahui dengan } \\
\text { yang ditanyakan sudah tepat. } \\
\text { 3.2 Memutuskan strategi/cara yang tepat untuk menyelesaikan } \\
\text { soal yang diberikan. } \\
\text { 3.3 Memutuskan bahwa konsep matematika yang digunakan sudah } \\
\text { sesuai untuk menyelesaikan soal yang diberikan. }\end{array}$ & $\begin{array}{l}\text { Semua } \\
\text { indikator } \\
\text { tidak } \\
\text { terpenuhi }\end{array}$ \\
\hline
\end{tabular}

\begin{tabular}{cl}
\hline & Melaksanakan rencana penyelesaian \\
& 1. Perencanaan (planning) \\
Tinggi $\quad$ Merencanakan pelaksanaan rencana penyelesaian, antara lain: \\
1.1 Merencanakan untuk melaksanakan strategi/cara yang dipilih. \\
1.2 Merencanakan untuk melakukan perbaikan bila menemukan \\
kesalahan. \\
2. Pemantauan (monitoring) \\
Melaksanakan dan memantau langkah penyelesaian yang dilakukan \\
berdasarkan rencana, antara lain: \\
2.1 Memantau setiap langkah pada jawaban yang diberikan sudah \\
benar atau tidak. \\
2.2 Memantau langkah perbaikan berada dijalur yang benar atau \\
tidak. \\
3. Evaluasi (evaluating) \\
Mengevaluasi langkah yang dilakukan sudah sesuai dengan rencana, \\
antara lain: \\
3.1 Memutuskan bahwa setiap langkah pada jawaban yang diberikan \\
sudah benar. \\
3.2 Memutuskan bahwa perbaikan yang dilakukan telah sesuai dan \\
mampu memperbaiki kesalahan.
\end{tabular}

Semua indikator terpenuhi Indikator 2.2 dan 3.2 tidak terpenuhi Indikator 1.1 terpenuhi untuk semua soal

\section{Memeriksa Kembali}

\section{Perencanaan (planning)}

Merencanakan akan memeriksa kembali setiap langkah yang Tinggi dilakukan, antara lain:
1.1 Merencanakan akan memeriksa kembali ketepatan jawaban yang diperoleh sesuai dengan yang ditanyakan.
1.2 Merencanakan permasalahan yang diberikan dapat diselesaikan dengan strategi/cara yang berbeda.

\section{Pemantauan (monitoring)}

Memantau setiap langkah dalam memeriksa kembali, antara lain:

Semua indikator terpenuhi

Sedang

2.1 Memeriksa kembali ketepatan jawaban yang diperoleh sesuai dengan yang ditanyakan.

Semua indikator tidak

2.2 Memantau pemilihan strategi/cara yang berbeda dalam terpenuhi permasalahan yang diberikan. 


\section{Kelompok \\ Pemecahan \\ Indikator Kemampuan Metakognisi dalam Pemecahan Masalah \\ Keterangan \\ Masalah}

3. Evaluasi (evaluating)

Memeriksa langkah yang dilakukan dalam memeriksa kembali sudah benar, antara lain:

3.1 Memutuskan bahwa ketepatan jawaban yang diperoleh sesuai dengan yang ditanyakan.

Rendah

3.2 Memutuskan memang dapat diselesaikan dengan strategi/cara yang berbeda dalam permasalahan yang diberikan.

Semua indikator tidak terpenuhi

3.3 Memutuskan bahwa strategi/cara yang digunakan efektif untuk menyelesaikan suatu permasalahan yang diberikan.

Berdasarkan Tabel 1, tampak bahwa kemampuan metakognisi dalam pemecahan masalah yang dilakukan siswa bervariasi. Hasil dari tes pemecahan masalah tersebut diperoleh bahwa subjek dengan kemampuan tinggi dapat dikatakan berhasil dalam menyelesaikan soal pemecahan masalah tersebut. Subjek dengan kemampuan tinggi dapatmenyelesaikan atau memperoleh nilai $80 \%$ dari nilai maksimal yang bisa didapat dari tes pemecahan masalah. Namun jika dilihat dari hasil tes uraian tersebut siswa tersebut belum dapat melakukan metakognitif dengan baik, karena masih ditemukan beberapa cara yang keliru atau salah penulisan dalam menjawab soal.

Untuk subjek berkemampuan sedang, peneliti memperoleh hasil bahwa nilai dari subjek dengan kemampuan sedang hanya dapat menyelesaikan dengan benar setengah dari jumlah soal yang ada. Dari hasil tes uraian itu yang menyebabkan subjek tidak sukses dalam penyelesaian soal adalah tidak melakukan metakognitif dengan baik, tidak melakukan perencanaan terlebih dahulu hal ini terlihat subjek berusaha untuk langsung menyelesaikan soal tersebut tanpa menulis perencanaan sebelum menjawab soal tersebut. Pada saat wawancara untuk mengetahui proses metakognitifnya, subjek kemampuan sedang hanya bisa melakukan sampai tahap memantau jadi subjek kemampuan sedang metakognitifnya belum terlaksana semuanya.

Kemudian subjek yang ketiga yaitu siswa dengan kemampuan rendah. Hasil yang diperoleh terlihat bahwa siswa dengan kemampuan rendah tidak berhasil dalam menyelesaikan soal tes yang diberikan. Hal ini terlihat dengan hasil pekerjaan semuanya hanya dilakukan setengah dari keseluruhan proses, dan disaat dilakukan wawancara subjek kemampuan rendah terkendala dalam menentukan menyusun dan pemilihan strategi dalam pemecahna masalah dan memahami soal yang sudah diberikan.

\section{PENUTUP}

\section{Kesimpulan}

Berdasarkan hasil penelitian dan analisis data yang telah dilakukan dapat disimpulkan bahwa dapat diketahui kemampuan metakognitif 
seseorang dipengaruhi oleh tingkat kemampuan subjek. Hal ini terlihat bahwa subjek penelitian dengan kemampuan tinggi dapat menyelesaikan soal yang diberikan, hampir semua indikator terpenuhi pada masing-masing proses perencanaan (planning), pemantauan (monitoring), maupun evaluasi (evaluation). Untuk subjek dengan kemampuan sedang dalam pemecahan masalah tidak lebih baik dibanding kelompok tinggi saat merencanakan penyelesaian pada masing-masing proses perencanaan (planning), pemantauan (monitoring), maupun evaluasi (evaluation). Kemudian untuk subjek dengan rendah dalam pemecahan masalah semua indikator tidak terpenuhi pada masing-masing proses perencanaan (planning), pemantauan (monitoring), maupun evaluasi (evaluation).

\section{Saran}

Berdasarkan hasil penelitian yang telah dikemukakan, maka peneliti mengemukakan saran diantaranya adalah:

a. Dalam penelitian ini subjek penelitian yang dilibatkan kecil jadi untuk penelitian selanjutnya dapat melaksanakan dengan jumlah subjek yang lebih besar sehingga dapat dibedakan secara detail metakognitifnya. b. Hasil penelitian ini dapat menjadi bahan informasi atau sumber referensi bagi peneliti maupun calon peneliti dalam melakukan penelitian selanjutnya yang berhubungan dengan variabel pada penulisan ini demi pengembangan hasil belajar matematika pada masa yang akan datang.

\section{DAFTAR PUSTAKA}

Anggo, M. (2011). Pelibatan Metakognisi dalam Pemecahan Masalah Matematika. Edumatica: Jurnal Pendidikan Matematika, 1(1), 25-32. https://doi.org/10.22437/edumatica.v1i01.188

Nurmalasari, L. R., Winarso, W., \& Nurhayati, E. (2015). Pengaruh Kemampuan Metakognisi terhadap Hasil Belajar Matematika di SMP Negeri 2 Leuwimunding Kabupaten Majalengka. Nusantara of Research, 2(02), 133-147.

Putri, A. P., \& Tayeb, T. (2017). Kemampuan Metakognisi untuk Meningkatkan Keterampilan Pemecahan Masalah Matematika Siswa Kelas VIII B MTs Madani Alauddin Paopao Kabupaten Gowa. MaPan: Jurnal Matematika Dan Pembelajaran, 5(1), 1-17. https://doi.org/10.24252/mapan.2017v5n 1a1

Sugiyono. (2012). Metode Penelitian Kuantitatif Kualitatif dan R\&B. Bandung: Alfabeta. 